\title{
ANALISIS BUTIR SOAL UJIAN AKHIR MATA PELAJARAN EKONOMI AKUNTANSI
}

\section{TEST ITEM ANALYSIS OF FINAL EXAMINATION IN ECONOMIC ACCOUNTING SUBJECT}

Oleh:

Wika Sevi Oktanin

Pendidikan Akuntansi Universitas Negeri Yogyakarta

seviwika@yahoo.co.id

Sukirno

Staf Pengajar Jurusan Pendidikan Akuntansi Universitas Negeri Yogyakarta

\begin{abstract}
Abstrak
Penelitian ini bertujuan untuk mengetahui kualitas soal ujian akhir semester genap mata pelajaran Ekonomi Akuntansi Kelas XI IPS SMA N 1 Kalasan Tahun Ajaran 2013/2014. Penelitian ini merupakan penelitian deskriptif kuantitatif. Soal tersebut dianalisis berdasarkan Validitas, Reliabilitas, Daya Pembeda, Tingkat Kesukaran, dan Efektivitas Pengecoh. Teknik pengumpulan data dilakukan dengan metode dokumentasi dan data dianalisis menggunakan program Anates Versi 4 serta perhitungan manual dengan bantuan excel. Hasil penelitian menunjukkan bahwa soal ujian akhir semester genap mata pelajaran Ekonomi Akuntansi Kelas XI IPS SMA N 1 Kalasan Tahun Ajaran 2013/2014 merupakan soal yang belum berkualitas baik. (1) Validitas soal menunjukkan 26 butir soal atau 52\% dikatakan valid dan 24 butir soal atau $48 \%$ dikatakan tidak valid sehingga soal termasuk soal yang berkualitas baik dari segi Validitas. (2) Reliabilitas soal sebesar 0,727 sehingga soal termasuk soal yang berkualitas baik karena koefisien Reliabilitas yang tinggi. (3) Daya Pembeda soal menunjukkan 33 butir soal atau 66\% memiliki daya pembeda jelek, 11 butir soal atau 22\% memiliki daya pembeda cukup, 3 butir soal atau 6\% memiliki daya pembeda baik, dan 3 butir soal atau $6 \%$ memiliki daya pembeda tidak baik sehingga soal termasuk soal yang belum berkualitas baik dari segi Daya Pembeda. (4) Tingkat Kesukaran soal menunjukkan 5 butir soal atau $10 \%$ tergolong sukar, 15 butir soal atau 30\% tergolong sedang, dan 30 butir soal atau $60 \%$ tergolong mudah sehingga soal termasuk soal yang belum berkualitas baik dari segi Tingkat Kesukaran. (5) Efektivitas Pengecoh soal menunjukkan 1 butir soal atau 2\% memiliki pengecoh sangat baik, 7 butir soal atau 14\%memiliki pengecoh baik, 15butir soal atau 30\%memiliki pengecoh cukup, 14 butir soal atau $28 \%$ memiliki pengecoh kurang baik, dan13 butir soal atau 26\% memiliki pengecoh tidak baik sehingga soal termasuk soal yang belum berkualitas baik dari segi Efektivitas Pengecoh.
\end{abstract}

Kata kunci: Analisis Butir Soal, Ekonomi Akuntansi, SMA N 1 Kalasan

\section{Abstract}

The purpose of this research is to find out about the quality of even semester final exam question in Economic Accounting subject Class XI IPS SMA N 1 Kalasan School Year 2013/2014. This research is a descriptive quantitative research. Test was analyzed based on Validity, Reliability, Discriminatory Power, Difficulty Index, and Effectiviness of Distractor. The engineering of data collection was done by documentation method and the data was 
analized by Anates Version 4 Program as well as manual calculation with excel. The results show that the even semester final exam question in Economic Accounting subject class XI IPS SMA N 1 Kalasan School Year 2013/2014 has not good quality. (1) The Validity show that 26 items or 52\% are valid items and 24 items or $48 \%$ aren't valid items so the question has good quality from Validity's aspect. (2) The Reliability is 0,727 so the question has good quality from Reliability's aspect because that high coefficient Reliability. (3) Discriminatory Power show that 33 items or $66 \%$ have poor discriminatory power, 11 items or $22 \%$ have satisfactory discriminatory power, 3 items or $6 \%$ have good discriminatory power, and 3 items or 6\% have bad discriminatory power so the question has not good quality from Discriminatory Power's acpect. (4) Difficulty Index show that 5 items or $10 \%$ are difficult level, 15 items or $30 \%$ are medium level, and 30 items or $60 \%$ are easy level so the question has not good quality from Difficulty Index's aspect. (5) Effectiviness of Distractor show that 1 item or $2 \%$ has very good distractor, 7 items or $14 \%$ have good distractor, 15 items or $30 \%$ have sufficient distractor, 14 items or $28 \%$ have less well distractor, and 13 items or $26 \%$ have bad distractor so the question has not good quality from Effectiviness of Distractor's aspect.

Keywords: Test Item Analysis, Economic Accounting, SMA N 1 Kalasan

\section{PENDAHULUAN}

Pendidikan merupakan suatu proses yang tidak akan berhenti hingga akhir hayat seseorang. Pendidikan dapat diperoleh melalui jalur non formal, formal, dan informal. Ketiga jalur pendidikan tersebut merupakan sebuah kesinambungan dan saling melengkapi satu sama lain. Salah satu jalur pendidikan yang memberikan banyak kontribusi dalam menyalurkan pengetahuan adalah jalur pendidikan formal yaitu sekolah.

Sekolah melalui guru membekali peserta didiknya dengan berbagai pengetahuan yang tertuang dalam setiap mata pelajaran. Guru sebagai fasilitator bagi peserta didik memiliki peranan yang besar dalam mengantarkan peserta didik memperoleh hasil belajar yang baik. Dalam memenuhi peranannya tersebut, guru perlu memahami dan menguasai tentang evaluasi pembelajaran guna mengevaluasi hasil belajar peserta didiknya.

"Evaluasi merupakan salah satu komponen penting dan tahap yang harus ditempuh oleh guru untuk mengetahui keefektifan pembelajaran" (Zainal Arifin, 2012: 2). Dari kegiatan evaluasi khususnya evaluasi hasil belajar, guru dapat mengukur apakah peserta didik sudah menguasai materi yang telah dipelajari atau belum.
Dalam mengevaluasi hasil belajar peserta didik, guru dapat melakukannya melalui teknik tes dan teknik non tes. Teknik tes merupakan teknik yang sering digunakan oleh guru dalam bentuk ulangan harian, ujian tengah semester, dan ujian akhir semester. Menurut M. Ngalim Purwanto (2010: 33) tes hasil belajar adalah tes yang digunakan untuk menilai hasil pelajaran yang telah diberikan oleh guru kepada peserta didiknya. Tes yang diberikan oleh guru dapat dalam bentuk tes subjektif dan tes objektif. "Tes subjektif pada umumnya berbentuk esai (uraian)" (Suharsimi Arikunto, 2013: 177). Tes objektif menurut Suharsimi Arikunto (2013: 181-193) dapat berupa tes benar-salah (true-false), tes pilihan ganda (multiple choice test), tes menjodohkan (matching test), dan tes isian (completion test).

Tes yang baik tentunya dapat memberikan gambaran yang tepat mengenai hasil belajar peserta didik. Dengan kata lain tes yang baik haruslah tes yang berkualitas. Tes yang berkualitas menurut Suharsimi Arikunto (2013: 72) harus memenuhi persyaratan tes yaitu validitas, reliabilitas, objektivitas, kepraktisan, dan ekonomis. Tes dikatakan valid jika tes tersebut dapat memberikan informasi yang sesuai dan dapat digunakan untuk mencapai tujuan 
tertentu. Tes dikatakan reliabel jika tes tersebut akan selalu memberikan hasil yang sama jika tes tersebut diberikan pada kelompok yang sama pada waktu atau kesempatan yang berbeda. Tes dikatakan objektif apabila dalam pelaksanaan tes tidak ada faktor subjektif yang mempengaruhi, terutama dalam sistem skoringnya. Tes yang mengandung kepraktisan adalah tes yang mudah dalam mempersiapkan, menggunakan, mengolah dan mengadministrasikannya. Tes dikatakan ekonomis jika tes tersebut tidak membutuhkan biaya, tenaga, dan waktu yang banyak.

Analisis kualitas tes adalah tahap yang dapat ditempuh untuk mengetahui derajat kualitas tes baik keseluruhan tes maupun butir soal yang merupakan bagian dari tes (Zainal Arifin. 2012: 246). Derajat kualitas tes yang dikaji dari butir soal dapat diketahui melalui analisis butir soal. Analisis butir soal merupakan kegiatan mengkaji butir-butir pertanyaan dalam tes apakah sudah memenuhi syarat sebagai tes yang berkualitas (Anas Sudijono. 2012: 370). Dari analisis butir soal ini dapat diidentifikasikan butir soal mana yang baik dan tidak baik serta butir soal mana yang dapat masuk ke dalam bank soal, direvisi, atau dibuang. Analisis butir soal dapat dihitung melalui beberapa aspek yaitu Validitas, Reliabilitas, Daya Pembeda, Tingkat Kesukaran, Dan Efektivitas Pengecoh (Zainal Arifin. 2012: 246-280).

Di SMA N 1 Kalasan kualitas soal ujian akhir semester genap mata pelajaran Ekonomi Akuntansi kelas XI IPS belum diketahui. Hal tersebut dikarenakan guru mata pelajaran Ekonomi Akuntansi belum melaksanakan analisis butir soal terhadap tes yang digunakan dalam ujian akhir semester genap. Guru mata pelajaran Ekonomi Akuntansi masih memiliki keterbatasan waktu dan tenaga untuk melaksanakan analisis butir soal. Guru masih memiliki keterbatasan waktu untuk melaksanakan analisis butir soal karena guru memiliki beban mengajar di sekolah selama 7 jam dan selebihnya guru menggunakan waktunya di rumah untuk mengurus berbagai keperluan keluarga, membuat Rencana Pelaksanaan Pembelajaran (RPP) dan mempersiapkan materi serta media pembelajaran. Guru juga masih memiliki keterbatasan tenaga untuk melaksanakan analisis butir soal karena banyaknya tanggung jawab yang dimiliki oleh guru seperti menyususn perangkat pembelajaran, menyiapkan materi serta media pembelajaran, dan mengkoreksi hasil pekerjaan peserta didik yang semuanya dilaksankan sendiri oleh guru. Oleh karena itu, peneliti tertarik untuk melakukan penelitian mengenai kualitas soal ujian akhir semester genap dengan judul "Analisis Butir Soal Ujian Akhir Semester Genap Mata Pelajaran Ekonomi Akuntansi Kelas XI IPS SMA N 1 Kalasan Tahun Ajaran 2013/2014."

\section{METODE PENELITIAN}

\section{Subjek dan Objek Penelitian}

Subjek dalam penelitian ini adalah seluruh peserta didik kelas XI IPS yang berjumlah 81 peserta didik. Objek dalam penelitian ini adalah soal ujian akhir semester genap mata pelajaran ekonomi akuntansi kelas XI IPS tahun ajaran 2013/2014.

\section{Teknik Pengumpulan Data}

Penelitian ini menggunakan teknik dokumentasi. Dokumentasi digunakan untuk memperoleh data berupa silabus, soal ujian akhir semester genap mata pelajaran ekonomi akuntansi kelas XI IPS, kunci jawaban soal, dan lembar jawab seluruh peserta didik kelas XI IPS pada mata pelajaran ekonomi akuntansi.

\section{Teknik Analisis Data}

a. Validitas

Pengujian validitas butir Soal Ujian Akhir Semester Genap Mata Pelajaran Ekonomi Akuntansi Kelas XI IPS SMA N 1 Kalasan Tahun Ajaran 2013/2014 menggunakan program Anates versi 4. Validitas dihitung dengan rumus korelasi point berserial sebagai berikut. 


$$
r_{p b i}=\frac{M p-M t}{S t} \sqrt{\frac{p}{q}}
$$

Keterangan :

$\mathrm{r}_{\mathrm{pbi}}=$ korelasi point berserial

$\mathrm{Mp}=$ rerata skor dari subjek yang menjawab betul bagi item yang dicari validitasnya

$\mathrm{Mt}=$ rerata skor total

St $=$ standard deviasi dari skor total

$\mathrm{p}=$ proporsi siswa yang menjawab benar

$\mathrm{q}=$ proporsi siswa yang menjawab salah

(Suharsimi Arikunto, 2013: 93)

Dalam menginterpretasikan hasil perhitungan validitas butir soal, harga koefisien korelasi dibandingkan dengan tabel harga kritik $r$ product moment dengan taraf signifikansi $1 \%$. Apabila $\mathrm{r}_{\mathrm{pbi}} \geq \mathrm{r}_{\text {tabel }}$ maka soal dikatakan valid.

\section{b. Reliabilitas}

Reliabilitas butir Soal Ujian Akhir Semester Genap Mata Pelajaran Ekonomi Akuntansi Kelas XI IPS SMA N 1 Kalasan Tahun Ajaran 2013/2014 dihitung secara manual dengan bantuan excel. Reliabilitas dihitung dengan rumus $\mathrm{KR}_{20}$ sebagai berikut.

$$
r_{11}=\left(\frac{n}{n-1}\right)\left(\frac{S^{2}-\sum p q}{S^{2}}\right)
$$

Keterangan :

$$
\begin{aligned}
& r_{11}=\text { reliabilitas tes secara } \\
& \text { keseluruhan } \\
& \mathrm{n}=\text { banyaknya item } \\
& \mathrm{p} \quad=\text { proporsi subjek yang } \\
& \text { menjawab item dengan benar } \\
& \mathrm{q}=\text { proporsi subjek yang } \\
& \text { menjawab item dengan salah } \\
& \mathrm{S}=\text { standard deviasi dari tes } \\
& \text { (Suharsimi Arikunto, 2013: 115) }
\end{aligned}
$$

Pemberian interpretasiterhadap koefisien reliabilitas tes $\left(\mathrm{r}_{11}\right)$ pada umumnya digunakan patokansebagai berikut.

1) Apabila $r_{11}$ sama dengan atau lebih besardaripada 0,70 berarti tes hasil belajar yangsedang diuji reliabilitasnya dinyatakantelah memiliki reliabilitas yang tinggi (=reliable).

2) Apabila $r_{11}$ lebih kecil daripada 0,70berarti bahwa tes hasil belajar yangsedang diuji reliabilitasnya dinyatakanbelum memiliki reliabilitas yang tinggi(un-reliable).

(Anas Sudijono, 2012: 209)

c. Daya Pembeda

Perhitungan daya pembeda butir Soal Ujian Akhir Semester Genap Mata Pelajaran Ekonomi Akuntansi Kelas XI IPS SMA N 1 Kalasan Tahun Ajaran 2013/2014 dilakukan secara manual dengan menggunakan bantuan excel. Rumus yang digunakan untuk menghitung daya pembeda adalah sebagai berikut.

$$
\mathrm{D}=\frac{\mathrm{B}_{\mathrm{A}}}{\mathrm{J}_{\mathrm{A}}}-\frac{\mathrm{B}_{\mathrm{B}}}{\mathrm{J}_{\mathrm{B}}}=\mathrm{P}_{\mathrm{A}}-\mathrm{P}_{\mathrm{B}}
$$

Keterangan :

$$
\begin{aligned}
\mathrm{D}= & \text { indeks diskriminasi } \\
\mathrm{J}_{\mathrm{A}}= & \text { banyaknya } \\
& \text { kelompok atas } \\
\mathrm{J}_{\mathrm{B}}= & \text { banyaknya } \\
& \text { kelompok bawah peserta } \\
\mathrm{B}_{\mathrm{A}}= & \text { banyaknya peserta } \\
& \text { kelompok atas yang } \\
& \text { menjawab dengan benar } \\
\mathrm{B}_{\mathrm{B}}= & \text { banyaknya peserta } \\
& \text { kelompok bawah yang } \\
& \text { menjawab dengan benar } \\
\mathrm{P}_{\mathrm{A}}= & \text { proporsi peserta kelompok } \\
& \text { atas yang menjawab benar } \\
\mathrm{P}_{\mathrm{B}}= & \text { proporsi peserta kelompok } \\
& \text { bawah yang menjawab } \\
& \text { benar }
\end{aligned}
$$
$\mathrm{P}_{\mathrm{B}} \quad=$ proporsi peserta kelompok bawah yang menjawab benar

(Suharsimi Arikunto, 2013: 228-229)

Dalam melakukan intepretasi terhadap hasil perhitungan daya pembeda dapat digunakan kriteria sebagai berikut.
D : $0,00-0,20$ : jelek (poor)
D : $0,21-0,40$ : cukup (satisfactory)
D : $0,41-0,70$ : baik (good)
D : $0,71-1,00$ : baik sekali (excellent) 
D : negatif, semuanya tidak baik. Jadi semua butir soal yang mempunyai nilai D negatif sebaiknya dibuang saja.

(Suharsimi Arikunto, 2013: 232)

\section{d. Tingkat Kesukaran}

Perhitungan tingkat kesukaran butir Soal Ujian Akhir Semester Genap Mata Pelajaran Ekonomi Akuntansi Kelas XI IPS SMA N 1 Kalasan Tahun Ajaran 2013/2014 menggunakan program Anates versi 4. Tingkat kesukaran soal dihitung dengan rumus berikut.

Keterangan :

$$
P=\frac{B}{J S}
$$

$\mathrm{P}=$ Indeks kesukaran

$\mathrm{B}=$ Banyaknya siswa yang menjawab soal dengan betul

$\mathrm{Js}_{\mathrm{s}}=$ Jumlah seluruh siswa peserta tes

(Suharsimi Arikunto, 2013: 223)

Dalam menginterpretasikan hasil perhitungan tingkat kesukaran soal dapat mennggunakan kriteria sebagai berikut.

Soal dengan P 0,00 sampai 0,30 adalah soal sukar

Soal dengan P 0,31 sampai 0,70 adalah soal sedang

Soal dengan P 0,71 sampai 1,00 adalah soal mudah

(Suharsimi Arikunto, 2013: 225)

\section{e. Efektivitas Pengecoh}

Perhitungan efektivitas pengecoh butir Soal Ujian Akhir Semester Genap Mata Pelajaran Ekonomi Akuntansi Kelas XI IPS SMA N 1 Kalasan Tahun Ajaran 2013/2014 menggunakan program Anates versi 4. Efektivitas pengecoh dihitung dengan rumus sebagai berikut.

$$
\mathrm{IP}=\frac{\mathrm{P}}{(\mathrm{N}-\mathrm{B}) /(\mathrm{n}-1)} \times 100 \%
$$

\section{Keterangan :}

IP $\quad=$ indeks pengecoh

$\mathrm{P} \quad=$ jumlah peserta didik yang memilih pengecoh

$\mathrm{N} \quad=$ jumlah peserta didik yang ikut tes

$$
\begin{aligned}
\mathrm{B} & =\underset{\text { jumlah peserta didik yang }}{ } \\
& \text { menjawab benar pada setiap soal } \\
\mathrm{n} & =\text { jumlah alterbatif jawaban (opsi) } \\
1 & =\text { bilangan tetap }
\end{aligned}
$$

(Zainal Arifin, 2012: 279)

Dalam menginterpretasikan hasil perhitungan setiap pengecoh pada suatu butir soal dapat menggunakan kriteria sebagai berikut.

Sangat baik

Baik

$$
\begin{aligned}
\mathrm{IP}= & 76 \%-125 \% \\
\mathrm{IP}= & 51 \%-75 \% \text { atau } \\
& 126 \%-150 \%
\end{aligned}
$$

Kurang Baik $\quad \mathrm{IP}=26 \%-50 \%$ atau $151 \%-175 \%$

Jelek IP $=0 \%-25 \%$ atau $176 \%-200 \%$

Sangat Jelek $\quad$ IP $=$ lebih dari $200 \%$

(Zainal Arifin, 2012: 280)

Dalam menyimpulkan efektivitas pengecoh pada setiap butir soal, peneliti menggunakan kriteria yang diadaptasi dari Skala Likert sebagai berikut (Sugiyono. 2010: 134-135).

Tabel 1. Kriteria Penilaian Efektivitas Pengecoh

\begin{tabular}{|c|l|}
\hline $\begin{array}{c}\text { Pengecoh yang } \\
\text { berfungsi }\end{array}$ & \multicolumn{1}{|c|}{ Kriteria } \\
\hline 4 & Sangat Baik \\
\hline 3 & Baik \\
\hline 2 & Cukup Baik \\
\hline 1 & Kurang baik \\
\hline 0 & Tidak Baik \\
\hline
\end{tabular}

Berikut ini penjelasan dari tabel kriteria penilaian efektivitas pengecoh di atas.

1) Jika keempat jawaban pengecoh berfungsi maka soal dikatakan memiliki efektivitas pengecoh yang sangat baik.

2) Jika terdapat tiga jawaban pengecoh yang berfungsi maka soal dikatakan memiliki efektivitas pengecoh yang baik.

3) Jika terdapat dua jawaban pengecoh yang berfungsi maka soal dikatakan 
memiliki efektivitas pengecoh yang cukup baik.

4) Jika terdapat 1 jawaban pengecoh yang berfungsi maka soal dikatakan memiliki efektivitas pengecoh yang kurang baik.

5) Jika semua jawaban pengecoh tidak berfungsi maka soal dikatakan memiliki efektivitas pengecoh yang tidak baik.

f. Kriteria Kualitas Soal

Dalam menginterpretasikan setiap butir soal, peneliti membagi kualitas soal menjadi lima yaitu: sangat baik, baik, sedang tidak baik, dan sangat tidak baik. Kriteria yang peneliti gunakan untuk menentukan tingkat kualitas butir soal diadaptasi dari Skala Likert sebagai berikut (Sugiyono. 2010: 134-135).

\section{Tabel 2. Kriteria Kualitas Butir Soal}

\begin{tabular}{|c|l|l|l|}
\hline $\begin{array}{c}\text { Jumlah } \\
\text { kriteria } \\
\text { yang } \\
\text { terpenuhi }\end{array}$ & $\begin{array}{l}\text { Kualitas } \\
\text { Butir } \\
\text { Soal }\end{array}$ & Revisi & $\begin{array}{c}\text { Masuk } \\
\text { Bank } \\
\text { Soal }\end{array}$ \\
\hline 4 & $\begin{array}{l}\text { Sangat } \\
\text { Baik }\end{array}$ & $\begin{array}{l}\text { Tidak } \\
\text { ada }\end{array}$ & Ya \\
\hline 3 & Baik & Minor & Belum \\
\hline 2 & Sedang & Sedang & Belum \\
\hline 1 & $\begin{array}{l}\text { Tidak } \\
\text { Baik }\end{array}$ & Dibuang & Tidak \\
\hline 0 & $\begin{array}{l}\text { Sangat } \\
\text { Tidak } \\
\text { Baik }\end{array}$ & Dibuang & Tidak \\
\hline
\end{tabular}

Berikut ini penjelasan dari tabel kriteria kualitas butir soal di atas.

1) Butir soal dikatakan sangat baik apabila memenuhi 4 kriteria soal yang baik yaitu validitas, tingkat kesukaran, daya pembeda, dan efektivitas pengecoh. Pada kondisi ini butir soal bisa masuk ke bank soal.

2) Butir soal dikatakan baik jika memenuhi 3 kriteria dari 4 kriteria soal yang baik (validitas, tingkat kesukaran, daya pembeda, dan efektivitas pengecoh). Pada kondisi ini butir soal belum bisa masuk ke bank soal. Soal harus direvisi hingga memenuhi empat kriteria.

3) Butir soal dikatakan sedang jika memenuhi 2 kriteria dari 4 kriteria soal yang baik (validitas, tingkat kesukaran, daya pembeda, dan efektivitas pengecoh). Pada kondisi ini butir soal belum bisa masuk ke bank soal. Soal harus direvisi hingga memenuhi empat kriteria.

4) Butir soal dikatakan tidak baik jika memenuhi 1 dari 4 kriteria sebagai soal yang baik (validitas, tingkat kesukaran, daya pembeda, dan efektivitas pengecoh). Pada kondisi ini butir soal tidak bisa masuk ke bank soal. Soal membutuhkan revisi signifikan sehingga lebih baik dibuang.

5) Butir soal dikatakan sangat tidak baik jika tidak memenuhi seluruh kriteria sebagai soal yang baik (validitas, tingkat kesukaran, daya pembeda, dan efektivitas pengecoh). Pada kondisi ini butir soal tidak bisa masuk ke bank soal. Soal membutuhkan revisi signifikan sehingga lebih baik dibuang.

6) Selain syarat berbasis butir, maka tes secara keseluruhan harus reliabel dengan ketentuan sebagaimana dijelaskan di muka.

\section{HASIL PENELITIAN DAN PEMBA- HASAN}

1. Validitas

Validitas soal ujian akhir semester genap mata pelajaran ekonomi akuntansi kelas XI IPS SMA N 1 Kalasan tahun ajaran 2013/2014 diuji dari segi tes secara totalitas melalui pengujian secara rasional (logis) dan dari segi item atau butir soal. Secara rasional, validitas soal dilihat dari segi kesesuaian isi soal dengan materi pelajaran dan indikatornya. Dari hasil analisis, soal ujian akhir semester genap mata pelajaran Ekonomi Akuntansi kelas XI IPS telah valid jika dilihat dari segi 
validitas logis. Hal ini dikarenakan isi soal telah sesuai dengan indikator dan materi yang dipelajari di kelas XI IPS.

Dari segi item soal, validitas butir soal ujian akhir semester genap mata pelajaran Ekonomi Akuntansi kelas XI IPS dihitung dengan menggunakan rumus Indeks Point Biserial ( $\mathrm{r}_{\mathrm{pbi}}$ ) dengan taraf $\begin{array}{lll}\text { signifikansi } \quad 1 \% & (0,284) \text {. }\end{array}$ Jika $r_{\text {pbi }}$ atau $r_{\text {hitung }} \geq r_{\text {tabel }}$ maka soal dikatakan valid.

Berdasarkan hasil analisis, menunjukkan bahwa butir soal yang valid berjumlah 26 butir atau $52 \%$ dan butir soal yang tidak valid berjumlah 24 butir atau $48 \%$. Jadi, dapat dikatakan soal ujian akhir semester genap mata pelajaran ekonomi akuntansi kelas XI IPS dapat mengukur apa yang seharusnya diukur.

\section{Reliabilitas}

Berdasarkan perhitungan reliabilitas secara manual dengan menggunakan excel, diperoleh hasil $r_{11}=0,727$. Hasil perhitungan tersebut menunjukkan bahwa soal ujian akhir semester genap mata pelajaran Ekonomi Akuntansikelas XI IPS memiliki reliabilitas yang tinggi karena $r_{11} \geq 0,70$.

Dari uraian di atas, dapat disimpulkan jika soal ujian akhir semester genap mata pelajaran Ekonomi Akuntansi kelas XI IPS merupakan soal yang berkualitas baik dari segi reliabilitasnya. Reliabilitas soal yang tinggi diperoleh karena jumlah butir soal yang cukup banyak dan soal tersebut diujikan kepada kelompok yang terdiri dari banyak siswa.

\section{Daya Pembeda}

Berdasarkan hasil analisis, butir soal yang memiliki daya pembeda jelek berjumlah 33 butir atau $66 \%$, butir soal yang memiliki daya pembeda cukup berjumlah 11 butir atau $22 \%$, butir soal yang memiliki daya pembeda baik berjumlah 3 butir atau $6 \%$, dan butir soal yang memiliki daya pembeda tidak baik berjumlah 3 butir atau $6 \%$.
Jadi, dapat disimpulkan bahwa soal ujian akhir semester genap mata pelajaran Ekonomi Akuntansi kelas XI IPS tahun ajaran 2013/2014 merupakan soal yang belum berkualitas baik dari segi daya pembedanya karena soal tidak dapat membedakan antara kelompok atas dan kelompok bawah.

\section{Tingkat Kesukaran}

Berdasarkan hasil analisis, butir soal yang tergolong sukar berjumlah 5 butir atau $10 \%$, butir soal yang tergolong sedang berjumlah 15 butir atau $30 \%$, dan butir soal yang tergolong mudah berjumlah 30 butir atau $60 \%$.

Jadi, dapat disimpulkan bahwa soal ujian akhir semester genap mata pelajaran Ekonomi Akuntansi kelas XI IPS merupakan soal yang belum berkualitas baik dari segi tingkat kesukarannya. Hal ini dikarenakan soal yang tergolong sedanghanya 15 butir dari 50 butir soal yang ada. Soal yang tergolong mudah dan sukar sebanyak 35 butir soal dan butir soal tersebut harus diperbaiki.

\section{EfektivitasPengecoh}

Berdasarkan hasil analisis, terdapat 1 butir soal (2\%) yang memiliki pengecoh sangat baik, 7 butir soal (14\%) yang memiliki pengecoh baik, 15butir soal $(30 \%)$ yang memiliki pengecoh cukup, 14 butir soal (28\%) yang memiliki pengecoh kurang baik, dan13butir soal (26\%) yang memiliki pengecoh tidak baik. Dari uraian di atas, dapat disimpulkan bahwa soal ujian akhir semester genap mata pelajaran Ekonomi Akuntansikelas XI IPS merupakan soal yang belum berkualitas baik dari segi efektivitas pengecoh. Hal tersebut dikarenakan hanya 23 butir soal yang memiliki efektivitas pengecoh baik.

6. Kualitas Soal Ujian Akhir Semester Genap Mata Pelajaran Ekonomi Akuntansi Kelas XI IPS 
Hasil analisis Validitas, Daya Pembeda, Tingkat Kesukaran, dan Efektivitas Pengecoh butir soal kemudian dianalisis secara bersama-sama untuk mengetahui kualitas butir soal. Kualitas butir soal dibagi ke dalam lima kategori yaitu: sangat baik, baik, sedang, tidak baik, dan sangat tidak baik yang diadaptasi dari Skala Likert.

Dari hasil analisis, sebanyak 3 butir soal atau $6 \%$ termasuk soal berkualitas sangat baik, 9 butir soal atau $18 \%$ termasuk soal berkualitas baik, 9 butir soal atau $18 \%$ termasuk soal berkualitas sedang, 21 butir soal atau $42 \%$ termasuk soal berkualitas tidak baik, dan 8 butir soal atau $16 \%$ termasuk soal berkualitas sangat tidak baik. Butir soal yang kualitasnya sangat baik bisa dimasukkan ke dalam bank soal dengan tetap menjaga kerahasiaan soal tersebut sehingga dapat digunakan lagi untuk ujian yang akan datang. Butir soal yang kualitasnya baik dan sedang belum bisa dimasukkan ke dalam bank soal karena harus dilakukan revisi terlebih dahulu sesuai dengan indikator kegagalannya. Butir soal yang kualitasnya tidak baik dan sangat tidak baik lebih baik dibuang karena butir tersebut membutuhkan revisi yang signifikan.

Hasil analisis menunjukkan sebanyak 19 butir soal memerlukan revisi dan 28 butir soal yang lebih baik dibuang. Hal tersebut menunjukkan bahwa butir soal belum bisa menjalankan fungsinya dengan baik. Penyebab kegagalan butir soal tersebut dapat ditelusuri dari aspek validitas, daya pembeda, tingkat kesukaran, dan efektivitas pengecoh tiap butir soal.

Penyebab kegagalan butir soal pertama yaitu pada daya pembeda. Hal tersebut menunjukkan bahwa soal yang digunakan belum dapat membedakan antara kelompok atas dengan kelompok bawah.

Penyebab kegagalan butir soal keduayaitu pada tingkat kesukaran. Dari segi tingkat kesukaran, soal ujian akhir semester genap mata pelajaran Ekonomi Akuntansi kelas XI IPS masih termasuk soal yang mudah sehingga belum bisa mengukur kemampuan peserta tes dengan baik.

Penyebab kegagalan butir soal yang ketiga yaitu pada efektivitas pengecoh. Dari segi efektivitas pengecoh, soal ujian akhir semester genap mata pelajaran Ekonomi Akuntansi kelas XI IPS memiliki pengecoh yang belum berfungsi dengan baik. Pengecoh yang tidak baik tersebut perlu diperbaiki ataupun dihilangkan.

Penyebab kegagalan butir soal keempat yaitu pada validitas soal. Hal tersebut menunjukkan bahwa validitas setiap butir soal belum memiliki dukungan besar terhadap skor total tes.

Dari uraian di atas, dapat disimpulkan jika soal ujian akhir semester genap mata pelajaran Ekonomi Akuntansi kelas XI IPS merupakan soal yang belum berkualitas baik. Hal tersebutdikarenakan hanya ada 3 butir soal yang berkualitas sangat baik dan dapat langsung disimpan di bank soal sedangkan untuk 18 butir soal memerlukan revisi baik revisi minor maupun sedang sesuai dengan indikator kegagalannya dan 29 butir soal lebih baik dibuang karena memerlukan revisi yang signifikan.

\section{SIMPULAN DAN SARAN}

\section{Kesimpulan}

Berdasarkan hasil analisis butir soal dari segi Validitas, Reliabilitas, Daya Pembeda, Tingkat Kesukaran, dan Efektivitas Pengecoh, maka dapat disimpulkan bahwa soal ujian akhir semester genap mata pelajaran Ekonomi Akuntansi kelas XI IPS SMA N 1 Kalasan tahun ajaran 2013/2014 merupakan soal yang belum berkualitas baik. Hal tersebut diperoleh dari hasil analisis butir soal sebagai berikut. 
a. Validitas sebagian besar butir soal ujian akhir semester genap mata pelajaran Ekonomi Akuntansi Kelas XI IPS SMA N 1 Kalasan tahun ajaran 2013/2014 menunjukkan butir soal yang valid sehingga soal termasuk soal yang berkualitas baik dari segi Validitasnya.

b. Reliabilitas soal ujian akhir semester genap mata pelajaran Ekonomi Akuntansi Kelas XI IPS SMA N 1 Kalasan tahun ajaran 2013/2014 tinggi sehingga soal termasuk soal yang berkualitas baik dari segi Reliabilitasnya.

c. Daya Pembeda sebagian besar butir soal ujian akhir semester genap mata pelajaran Ekonomi Akuntansi Kelas XI IPS SMA N 1 Kalasan tahun ajaran 2013/2014 memiliki kualitas yang jelek sehingga soal termasuk soal yang belum berkualitas baik dari segi Daya Pembeda.

d. Tingkat Kesukaran sebagian besar butir soal ujian akhir semester genap mata pelajaran Ekonomi Akuntansi Kelas XI IPS SMA N 1 Kalasan tahun ajaran 2013/2014 masih tergolong mudah sehingga soal termasuk soal yang belum berkualitas baik dari segi Tingkat Kesukaran.

e. Efektivitas Pengecoh sebagian besar butir soal ujian akhir semester genap mata pelajaran Ekonomi Akuntansi Kelas XI IPS SMA N 1 Kalasan tahun ajaran 2013/2014 belum berkualitas baik sehingga soal termasuk soal yang belum berkualitas baik dari segi Efektivitas Pengecoh.

\section{Saran}

a. Soal yang berkualitas sangat baik yaitu nomor 21, 37, dan 50 dapat disimpan di bank soal untuk dipakai lagi di ujian yang akan mendatang.

b. Soal yang berkualitas baik yaitu nomor 4, 10, 16, 19, 23, 38, 42, 45, dan 47 serta soal yang berkualitas sedang yaitu nomor 1, 18, 20, 32, 33, $35,36,43$, dan 49 sebaiknya dilakukan revisi sesuai dengan indikator kegagalannya agar menjadi soal yang sangat baik.

c. Soal yang berkualitas tidak baik yaitu nomor $2,3,5,6,8,9,11,13,14,15$, $22,24,25,28,30,34,39,40,41,46$, dan 48 serta soal yang berkualitas sangat tidak baik yaitu nomor 7,12 , 17, 26, 27, 29, 31, dan 44 sebaiknya dibuang karena membutuhkan revisi yang signifikan.

d. Pihak pembuat soal ujian akhir semester genap mata pelajaran Ekonomi Akuntansi lebih meningkatkan kemampuan dan pemahaman dalam menyusun soal. Hal ini disebabkan soal yang berkualitas sangat baik, baik, dan sedang lebih sedikit dari soal yang berkualitas tidak baik dan sangat tidak baik. Di lain pihak soal yang berkualitas akan menggambarkan kondisi kompetensi siswa lebih baik dari pada soal yang tidak berkualitas.

e. Pihak pengembang program Anates Versi 4 melakukan pengembangan program sehingga keterbatasanketerbatasan yang ada pada Anates Versi 4 dapat dihilangkan. Pengembangan yang dapat dilakukan yaitu pada tingkat kesukaran sebaiknya menunjukkan juga hasil perhitungan secara desimal, pada daya pembeda sebaiknya ada pembedaan antara kelompok besar dan kelompok kecil, dan pada indeks kesukaran lebih baik menunjukkan 3 kriteria saja (sukar, sedang, dan mudah) agar sesuai dengan teori-teori yang ada di buku.

f. Perlu dilakukan analisis lebih lanjut mengenai klasifikasi butir soal yang dapat masuk ke dalam bank soal. 


\section{DAFTAR PUSTAKA}

Anas Sudijono. (2012). Pengantar Evaluasi Pendidikan. Jakarta: Rajawali Pers.

M. Ngalim Purwanto. (2010). Prinsipprinsip dan Teknik Evaluasi Pengajaran. Bandung: PT Remaja Rosdakarya.

Sugiyono. (2010). Metode Penelitian Pendidikan Pendekatan Kuantitatif,
Kualitatif, dan R\&D. Bandung: Alfabeta.

Suharsimi Arikunto. (2013). Dasar-dasar Evaluasi Pendidikan. Jakarta: Bumi Aksara.

Zainal Arifin. (2012). Evaluasi Pembelajaran. Bandung: PT Remaja Rosdakarya. 